\title{
УДК 553.98 .042 \\ СРАВНИТЕЛЬНАЯ ПЕТРОФИЗИЧЕСКАЯ ХАРАКТЕРИСТИКА ЮРСКИХ РАЗРЕЗОВ ОСТАНИНСКОГО И ДВУРЕЧЕНСКОГО МЕСТОРОЖДЕНИЙ (В СВЯЗИ С НЕФТЕГАЗОНОСНОСТЬЮ ДОЮРСКИХ ОТЛОЖЕНИЙ ТОМСКОЙ ОБЛАСТИ)
}

\author{
Алеева Анна Олеговна', \\ rastorguevaAO_90@mail.ru \\ Исаев Валерий Иванович', \\ isaevvi@tpu.ru \\ Лобова Галина Анатольевна', \\ lobovaga@tpu.ru \\ 1 Национальный исследовательский Томский политехнический университет, \\ Россия, 634050, г. Томск, пр. Ленина, 30.
}

Актуальность исследования обусловлена важностью воспроизводства и расширения ресурсной базы углеводородов Западной Сибири на основе оценки перспектив и освоения горизонта зоны контакта и коренного палеозоя, залежи в которых относятся к трудноизвлекаемым запасам.

Цель: последовательное обоснование критерия прогнозирования и поисков палеозойских залежей углеводородов, основанного на гипотезеаномальности петрофизических характеристик юрских пластов - уникальности «отражения» залежей палеозоя в геофизических параметрах перекрывающего мезозойско-кайнозойского разреза. Эта гипотеза была сформулирована и аргументирована ранее результатами изучения разрезов скважин Герасимовского месторождения с палеозойскими залежами нефти и Крапивинского месторождения с юрскими залежами нефтти.

Объекты: геофизические и петросииические параметры юрских пластов-коллекторов и интервалов баженовской свиты на Останинском нефтегазоконденсатном месторождении, имеющем залежи в доюрском основании, и на Двуреченском нефртяном месторождения только с юрскими залежами нефти.

Методы. Для характеристики юрских пластов-коллекторов выполнены петрофизические расчеты удельного электрического сопротивления, использовались данные индукционного каротажа и каротажа сопротивления по разрезам 28 скважин Останинского и Двуреченского месторождений. Для характеристики петрофизики аргиллитов баженовской свиты сделан качественный и количественный (статистический) анализ показаний методов потенциалов самопроизвольной поляризации, кажущегося conротивления и гамма-каротажа. Карбонатность пород пластов-коллекторов оценивалась по данным объемного газометрического метода.

Результаты. Установлено, что юрские пласты-коллекторы Останинского месторождения имеют для нефттенасыщенных пластов УЭС=11...21 ом ${ }^{*}$, для водонасыщенных пластов УЭС=5...9 ом рождения имеют для нефтенасыщенных пластов УЭС=6..12 омм, для водонасыщенных пластов УЭС=2...5 омм. Юрские пласты-коллекторы Останинского месторождения аномально, в 2 раза, более высокоомные, чем юрские пласты Двуреченского месторождения. Общая карбонатность юрских пластов Останинского месторождения составляет 5,4 \%, а Двуреченского - 1,1 \%. Показано, что на Останинском месторождении вариации показаний метода ПС $= \pm(0,5 \ldots 2,5)$ мВ, уровень УЭС $=32 \ldots 42$ ом $^{*}$ м, уровень естественной радиоактивности $36 \ldots 44$ мкР/ч. На Двуреченском месторождении вариации показаний ПС - $\pm(5,0 \ldots 8,0)$ мВ, уровень УЭС=95...111 омм, уровень естественной радиоактивности $40 \ldots 59$ мкР/ч. Результаты исследований на Останинском и Двуреченском месторождениях полностью согласуются с ранее высказанной и аргументированной гипотезой аномальности петрофизических характеристик юрского разреза, перекрывающего залежи доюрского НГК.

\section{Ключевые слова:}

Палеозойские залежи углеводородов, петрофизическая характеристика юрских пластов-коллекторов и баженовской свиты, уникальное «отражение» залежей палеозоя в геофизических параметрах юрского разреза, критерий прогнозирования и поисков палеозойских залежей углеводородов, Томская область.

\section{Введение}

Важным направлением воспроизводства и расширения ресурсной базы углеводородов (УВ) Западной Сибири является оценка перспектив и освоение доюрского нефтегазоносного комплекса [1-4], залежи в котором относятся к трудноизвлекаемой нефти $[5,6]$.

Критерии «зон разуплотнения» и концепция «главного источника» - основы стратегии и технологии поисков залежей углеводородов в доюрском основании [7]. Атрибутивный анализ сейсмических кубов - наиболее эффективный способ выявления и картирования зон разуплотнения [8].

О концепции «главного источника» высказываются два альтернативных варианта.
По первой концепции палеозойские отложения рассматриваются как самостоятельный нефтеаккумулирующий комплекс с высоким нефтегенерационным потенциалом, приводящий к восходящей миграции УВ-флюидов согласно геодинамическому механизму по каналам, приуроченным к тектоническим разломам, зонам рифтонеза и коллизии литосферных плит [9]. На самостоятельный очаг нефтеобразования в палеозойских отложениях указывает значительное отличие нафтидов палеозоя и коры выветривания от юрских, являющееся признаком самостоятельного генотипа палеозойской нефти [10]. О восходящей миграции углеводородов судят также и по геохими- 
ческим аномалиям ряда элементов, возникающим в отложениях, наиболее индикаторными среди которых являются уран и платиноиды.

Обоснование второй концепции сводится к следующему. Системный анализ геохимических и литолого-петрографических данных, а именно посредством геохимической корреляции состава нефтей и битумоидов нефтематеринских пород, выявляет направленность нисходящей вертикальной межпластовой миграции углеводородов из осадочных пород тюменской свиты в доюрский комплекс. Нисходящая миграция может осуществляться по механизму перетока флюидов по трещинам и кавернам под действием капиллярных сил [11]. Нисходящая миграция УВ может осуществляется по механизму диффузии в свободной парогазовой фазе с опережающим перемещением легких УВ [12]. Нисходящая миграция из более молодых в более древние отложения возможна по ослабленным зонам, образованным геодинамическим режимом растяжения [13].

И далее восходящая и нисходящая миграция углеводородов может быть следствием возникновения локальных диссипативных структур внутри глубинных геофлюидодинамических систем, сформированных повышенной геодинамической напряженностью [14].

Таким образом, многовариантный концептуальный подход к вопросу происхождения («главного источника») залежей нефти и газа в палеозое вызыва- ет существенную неоднозначность рекомендаций относительно стратегии поисков залежей не только в доюрском основании, но и в юрском комплексе.

Вместе с тем, как вследствие возможной восходящей, так и вследствие возможной нисходящей миграции химически агрессивной смеси УВ-флюидов происходят процессы наложенного эпигенеза, в результате которых горные породы испытывают вторичные преобразования, включая карбонатизацию транзитных пластов [15]. Следовательно, интенсивность вторичных процессов, выраженная в аномальности петрофизических характеристик транзитных пластов, может служить индикатором присутствия очагов генерации, путей миграции, терминальных точек (зон нефтесбора), т. е. может служить критерием их обнаружения.

Ранее в [16] в качестве возможного критерия прогнозирования и поисков палеозойских залежей УВ сформулирована гипотеза аномальности петрофизических характеристик транзитных пластов - уникальности «отражения» залежей палеозоя в геофизических параметрах перекрывающего мезозойскокайнозойского разреза. Эта гипотеза была аргументирована результатами изучения геофизических и петрофизических разрезов 63 поисковых и разведочных скважин, вскрывших палеозойские залежи нефти на Герасимовском месторождении и только юрские залежи нефти на Крапивинском месторождении (рис. 1).

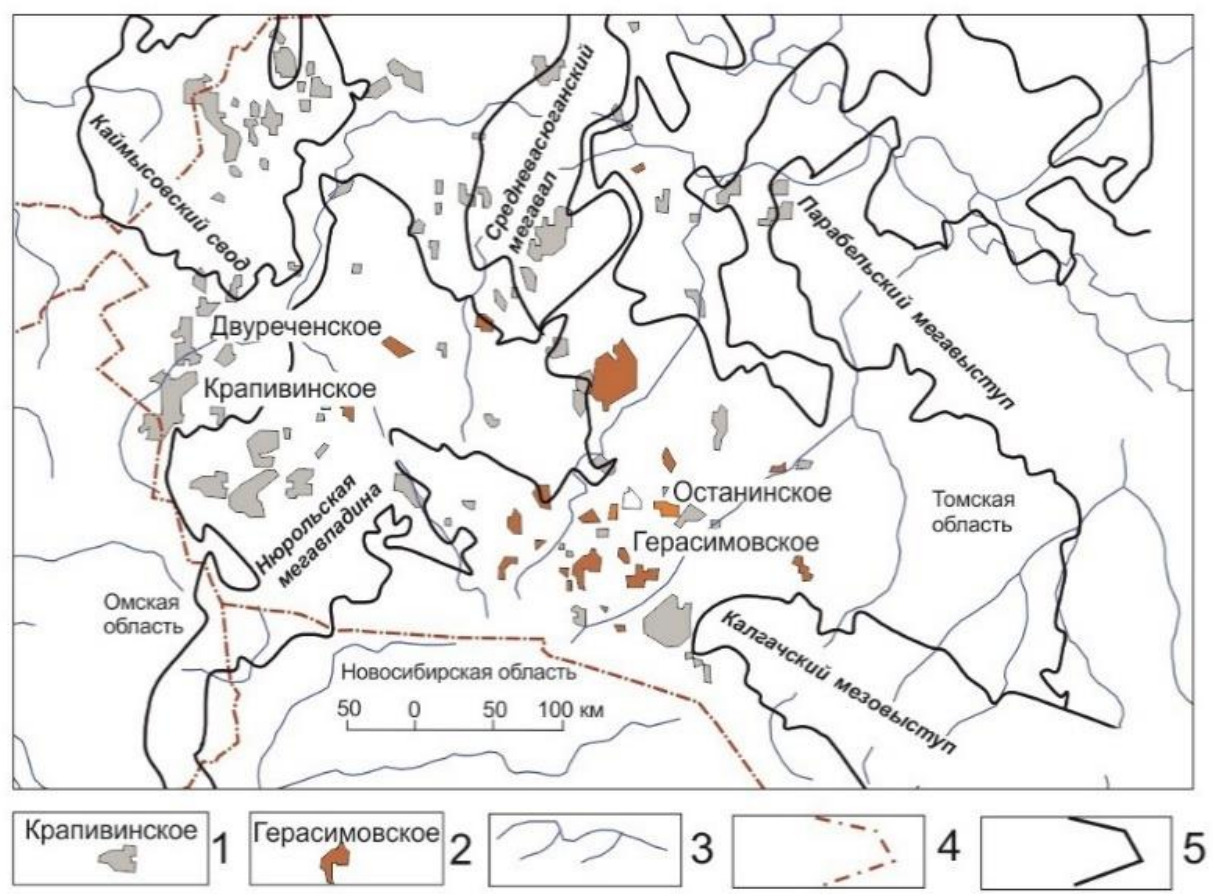

Pис. 1. Схематическая карта размещения месторождений углеводородов юго-запада Томской области: 1 - месторождение углеводородов с залежами в юрско-меловых нефтегазоносных комплексах; 2 -месторождение углеводородов с залежами в доюрском нефтегазоносном комплексе; 3 - гидросеть; 4 - административная гранииа областей; 5 - граница тектонических элементов I порядка платформенного чехла [16]

Fig. 1. Schematic map of the location of hydrocarbon deposits in the south-west of the Tomsk region: 1 is the hydrocarbon field with deposits in the Jurassic-Cretaceous oil and gas complexes; 2 is the hydrocarbon field with deposits in the pre-Jurassic oil and gas complex; 3 is the hydraulic network; 4 is the administrative border of the areas; 5 is the border of tectonic elements of the first order of the platform cover [16] 
Результаты изучения показали, что юрские пласты Герасимовского месторождения, имеющего залежи УВ в доюрском основании, отличаются от юрских пластов Крапивинского месторождения существенно более высокими значениями удельного электрического сопротивления (УЭС). Юрский разрез Герасимовского месторождения характеризуется УЭС=7...11 ом*м, а юрский разрез Крапивинского месторождения УЭС $=5 \ldots 7$ ом* м. Расчет интервального времени твердой фазы юрских пластов дал прогноз, что коллекторы Герасимовского месторождения карбонатизированы. Кроме того, было отмечено, что в интервале баженовской свиты Герасимовское месторождение отличается от Крапивинского месторождения спокойным характером диаграмм метода потенциалов самопроизвольной поляризации (ПС).

Здесь важно сослаться на новейшую публикацию томских коллег [17]. На примере Герасимовского месторождения исследована интенсивность вторичной карбонатизации юрских песчаных пластов и ее связь с характером насыщения палеозойских образований. Установлено, что интенсивность процесов вторичной карбонатизации является индикатором характера насыщения палеозойских пород. Подчеркнуто, что работа основана на концепции субвертикальной миграции УВ-флюидов, снизу в верх, от глубинного источника с разгрузкой в песчаных коллекторах. Обращено внимание, что для прогнозирования зон расположения залежей в фундаменте можно рационально и эффективно использовать материалы старого фонда скважин.

Для дальнейшего обоснования гипотезы аномального «отражения» залежей палеозоя в геофизических параметрах перекрывающих юрских отложений, как возможного критерия прогнозирования и поисков палеозойских залежей УВ, проведен анализ геофизических и петрофизических характеристик юрского разреза на Останинском нефтегазоконденсатном месторождении, имеющем залежи в доюрском основании, и на Двуреченском нефтяном месторождении только с юрскими залежами нефти (рис. 1).

Следует отметить, что по палеозою [18] Крапивинское и Двуреченское месторождения находятся в Туйско-Барабинской структурно-фациальной зоне (СФЗ), а Герасимовское и Останинское месторождения - в Нюрольской СФЗ. Однако по келловею и верхней юре [19] все изучаемые месторождения относятся к одной СФЗ - Пурпейско-Васюганской.

\section{Нефтегеологическая характеристика Останинского нефтегазоконденсатного месторождения}

Геология Останинского месторождения представлена образованиями доюрского фундамента и отложениями мезозойско-кайнозойского платформенного чехла. По тектоническому районированию фундамента площадь месторождения входит в состав южной части Нижневартовской антиклинорной зоны инверсионного типа, сложенной геосинклинальной карбонатно-глинисто-сланцевой формацией. Особенности тектонического развития территории в позднем палеозое и раннем мезозое обусловили блоковое строение фундамента. По тектоническому районированию платформенного чехла Останинская структура IV порядка приурочена к центральной части тектонической структуры II порядка - Пудинскому мезоподнятию (рис. 2, a).

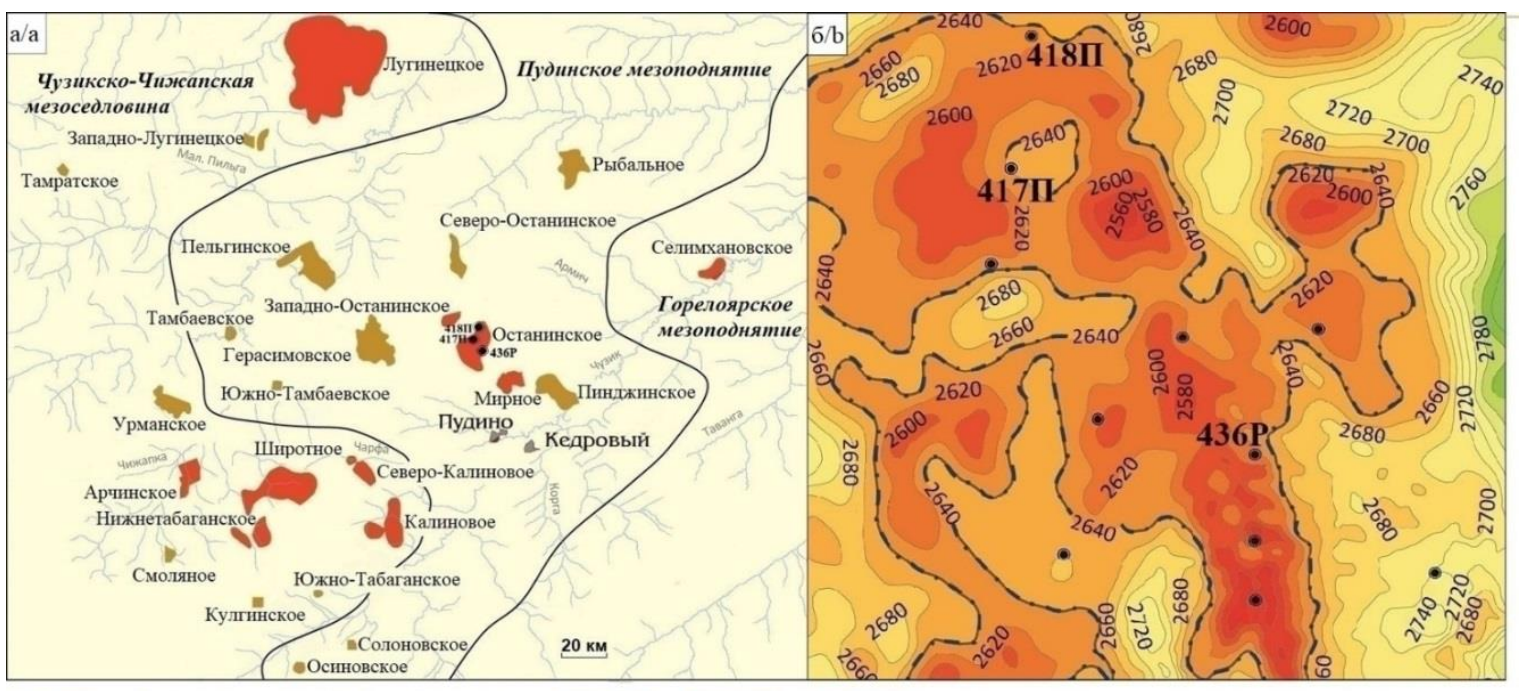

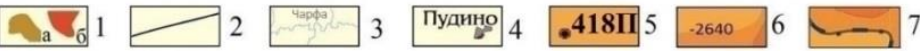

Pис. 2. Обзорная схема территории исследований Останинской группы месторождений углеводородов Томской области (а) и контур Останинского нефтегазоконденсатного месторождения (б). К а: 1 - месторождение УВ (а - нефтяное, $\sigma$ - нефтегазоконденсатное); 2 - контур тектонического элемента II-го порядка платформенного чехла [20]; 3 -речная сеть; 4 - населенный пункт. К б: 5 - скважина и ее номер; 6 - сейсмоизогипса отражающего горизонта $\Phi_{2}$ (подошва осадочного чехла); 7 - контур ВНК по пласту $M$

Fig. 2. Overview of the territory of research of the Ostaninskaya group of hydrocarbon fields of the Tomsk Region (a) and the contour of the Ostaninskoe oil and gas condensate field (b). To $a: 1$ is the hydrocarbon field ( $a$ is the oil, $b$ is the oil and gas condensate); 2 is the contour of a tectonic element of the second order of the platform cover [20]; 3 is the river network; 4 is the settlement. To b: 5 is the well and its number; 6 is the seismic isogypsum of the reflecting horizon $F_{2}$ (bottom of the sedimentary cover); 7 is the contour of the oil-water contact through the reservoir $M$ 
Нефтегазоносность Останинского месторождения приурочена к известнякам палеозойского фундамента (пласт $\mathrm{M}_{1}$ ), отложениям коры выветривания (пласт М), песчаным коллекторам тюменской (пласты $Ю_{3}, Ю_{4}$ ) и васюганской (пласты $Ю_{1}^{4}, Ю_{1}^{3}, Ю_{1}^{2}, Ю_{1}^{1}$ ) свит. Нефтеносными являются пласты $Ю_{1}{ }^{1}, \mathrm{M}$ и $\mathrm{M}_{1}$, газоносными - $Ю_{1}^{3}, Ю_{1}^{4}, Ю_{3}, Ю_{4}, \mathrm{M}$.

Пласты $Ю_{1}-Ю_{4}$. Изучаемый разрез пород васюганской и тюменской свит Останинского месторождения сложен породами прибрежно-морских и континентальных фаций. По данным литологопетрографических исследований коллекторы продуктивных пластов представлены средне-, мелкозернистыми песчаниками, переходящими местами в крупнозернистые алевролиты. Пористость коллекторов меняется от 12,6 до 14,4 \%. Проницаемость по пластам меняется в диапазоне - от 1,9 до 9,1 мД.

Продуктивные образования коры выветривания пласт M. Залежи углеводородов в коре выветривания на Останинском месторождении приурочены в основном к глинисто-кремнистым отложениям, формирование которых происходило за счет разрушения силикатосодержащих пород. К коре выветривания отнесены также брекчии (из базального слоя), образованные при разрушении и местном перемыве нижележащих глинисто-кремнистых пород. Пористость коллекторов меняется от 8,6 до $36,5 \%$, в среднем составляя $19,5 \%$. Проницаемость на керне не замерялась.

Продуктивные образования палеозоя - пласт $M_{1}$. По литолого-петрографическому описанию породы фундамента на Останинском месторождении представлены карбонатными породами - известняками. Коллекторы фундамента в основном водонасыщенные. Небольшая залежь УВ выделена по результатам испытаний только в скважине 418П. Пористость меняется от 0,2 до $6,7 \%$, в среднем составляя $1,7 \%$.

Геофизическая характеристика юрских пластов Останинского месторождения

Для анализа данных геофизических исследований юрских («транзитных»?) пластов Останинского месторождения были выбраны разрезы скважин с разной продуктивностью (например, скважина 417П с водонасыщенными пластами в юрской и в доюрской частях разреза и скважина 418П, вскрывшая залежи нефти в юрской части разреза и в доюрском основании, рис. 2, б).

Коллекторами в пластах $Ю_{1}{ }_{1}-Ю_{1}{ }^{3}$ являются песчаники и алевролиты с межзерновой структурой. Объект коры выветривания (пласт М) сложен переслаиванием глинисто-кремнистых пород. Фундамент сложен известняками трещинными и поровотрещинными, чистыми и глинистыми, плотными карбонатными прослоями и глинами. Коллекторами пласта $\mathrm{M}_{1}$ являются известняки трещинные и поровотрещинные.

Пласт $Ю_{1}{ }^{1}$ в разрезах изучаемых скважин выделяется как коллектор: глубокие отрицательные аномалии методов ПС и гамма-каротажа (ГК), повышение показаний нейтронного гамма-каротажа (НГК) и методов каротажа сопротивления (КС), понижение электропроводности по индукционному каротажу (ИК) (рис. 3). Георгиевская свита характеризуется отрицательной аномалией НГК и положительной ИК. Баженовская свита в изученных разрезах фиксируется классической [21] комплексной геофизической аномалией: высокой радиоактивностью, низкой электропроводностью, отличными от вмещающих пород показаниями нейтронного каротажа.

Кривая ПС остается неизменной по выделению пластов-коллекторов - характерными [22] отрицательными аномалиями разной амплитуды.

По геофизическим параметрам кора выветривания значительно отличается от юрского разреза и пласта $\mathrm{M}_{1}$. Кора выветривания более радиоактивна в сравнении с юрской частью разреза и пластом $\mathrm{M}_{1}$ (более $27 \mathrm{м \kappa P/ч} \mathrm{против} 11 \ldots 17$ мкР/час юрского разреза и $4 . . .9$ мкР/ч пласта $\mathrm{M}_{1}$ ) и отличается понижением показаний НГК $(1,4 \ldots 1,6$ против 1,6 ..2,0 юрского разреза и $2,4 \ldots 4,0$ пласта $\mathrm{M}_{1}$ ).

Пласт $\mathrm{M}_{1}$ характеризуется пониженной электропроводностью (показания ИК $0 \ldots 20$ мСим/м против $90 \ldots 120$ мСим/м юрского разреза и $30 \ldots 115$ мСим/м коры выветривания) и отличается от вышезалегающей коры выветривания аномально высокими показаниями КС.

Характерной особенностью юрского разреза скважины 418П является карбонатизация пород. Карбонатизация в юрской части разреза проявляется и локально, в виде отдельных слоев (например, интервалы $2487,8 \ldots 2489,5$ и $2520,2 \ldots .2521,2$ м). Карбонатизация развивается преимущественно по коллекторам и уверенно выделяется в показаниях каротажа как типичные [23] плотные песчаники: пониженными значениями ГК и высокими значениями КС и НГК.

Из каротажных диаграмм скважины 418П (рис. 3) видно, что юрский разрез, кора выветривания $(\mathrm{M})$ и пласт $\mathrm{M}_{1}$ имеют отличительные геофизические свойства, которые указывают на переход от терригенного разреза юрского возраста к карбонатному разрезу палеозоя.

Для характеристики петрофизики юрских пластов на Останинском месторождении использованы данные каротажа 14-ти поисковых и разведочных скважин (рис. 2, б) - материалы Томского филиала ФГУ «ТФГИ по СФО». Судя по результатам стандартного расчета УЭС [24] как нефтенасыщенных пластов, так и водонасыщенных пластов (табл. 1), юрские пластыколлекторы Останинского месторождения имеют существенно высокие значения: для нефтенасыщенных пла-

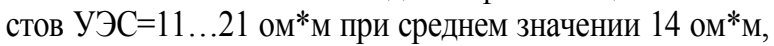
для водонасыщенных пластов УЭС $=5 \ldots 9$ ом*м при среднем значении $7 \mathrm{om}^{*} \mathrm{~m}$.

Геофизическая характеристика баженовской свиты Останинского месторождения

Для характеристики петрофизики аргиллитов баженовской свиты на Останинском нефтегазоконденсатном месторождении проанализированы разрезы скважин 417П, 418П и скважины 436Р, нефтепродуктивной в доюрской части (рис. 2). Был сделан анализ показаний методов ПС, КС, ГК и НГК (табл. 2). 


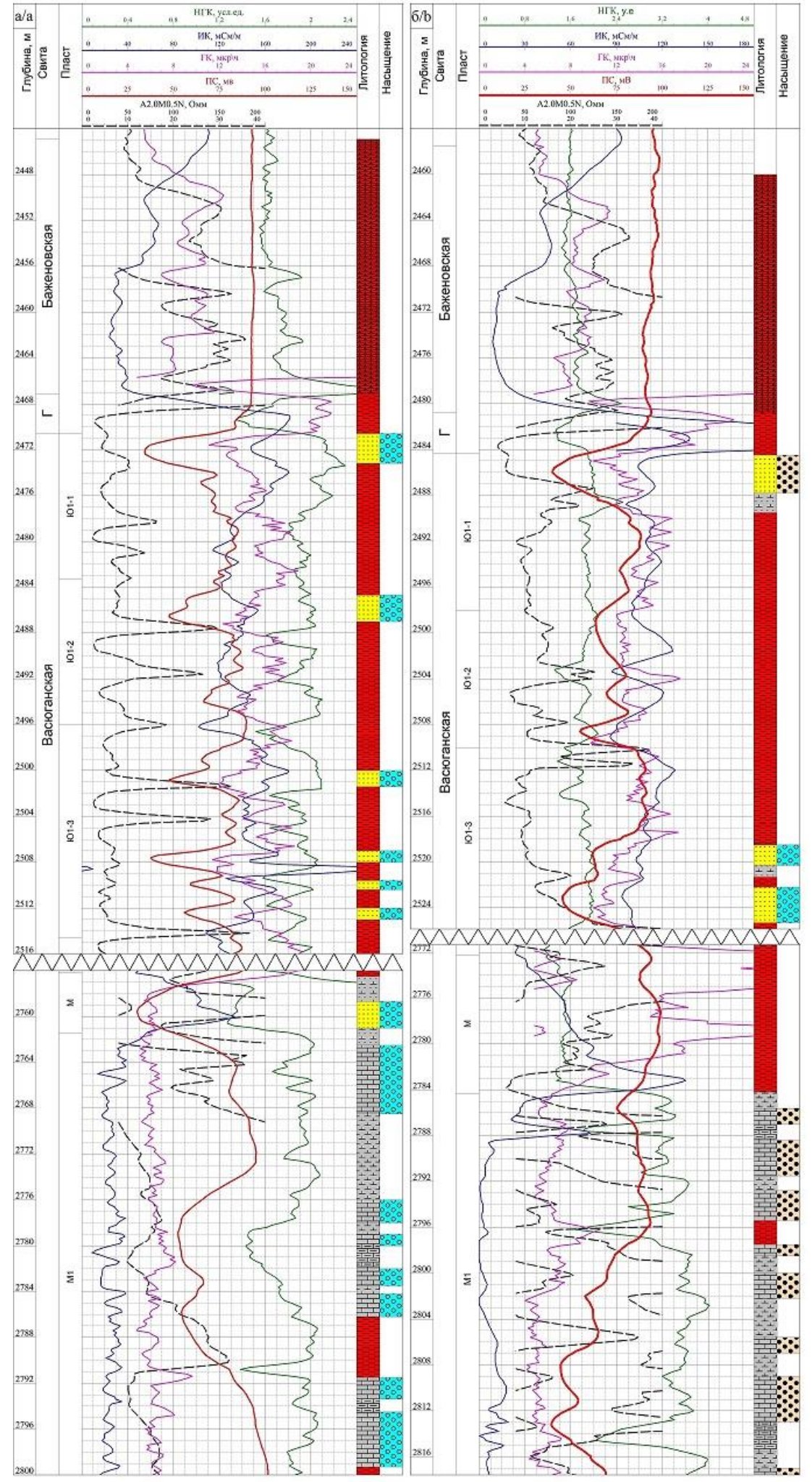

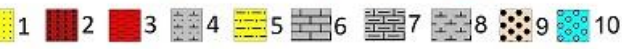

Pис. 3. Останинское месторождение. Геофизическая характеристика разрезов скважин $417 \Pi$ (а) и $418 \Pi$ (б) в ин-

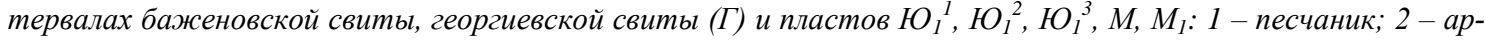
гиллит; 3 - глина; 4 - карбонатизированный песчаник; 5 - алевролит; 6 - известняк; 7 - глинистый известняк; 8-карбонатная порода; 9 - нефтенасыщенный; 10 - водонасыщенный

Fig. 3. Ostaninskoe field. Geophysical characteristics of the sections of wells $417 P(a)$ and $418 P(b)$ in the intervals of the Bazhenov suite, Georgiev suite $(G)$ and formations $J_{1}{ }^{1}, J_{1}{ }^{2}, J_{1}^{3}, M, M_{1}: 1$ is the sandstone; 2 is the argillite; 3 is the clay; 4 is the carbonated sandstone; 5 is the siltstone; 6 is the limestone; 7 is the clay limestone; 8 is the carbonate rock; 9 is the oil saturated; 10 is the water-saturated 
Таблица 1. Результаты расчета удельного электрического сопротивления $\rho_{n}$ нефтенасыщенных $\left(\rho_{\text {нп }}\right)$ и водонасыщенных $\left(\rho_{\text {вn }}\right)$ пластов Останинского месторождения

Table 1. Results of calculation of the electrical resistivity $R_{t}$ of oil-saturated $\left(R_{t}\right)$ and water-saturated $\left(R_{o}\right)$ layers of the Ostaninskoe field

\begin{tabular}{|c|c|c|c|c|}
\hline $\begin{array}{c}\text { Пласт } \\
\text { Formation }\end{array}$ & $\begin{array}{l}{ }^{*} \rho_{\text {нп, }}, \mathrm{om} \cdot \mathrm{M} \\
{ }^{*} \mathrm{R}_{\mathrm{t}}, \mathrm{om} \cdot \mathrm{m}\end{array}$ & $\begin{array}{c}\text { *коэффициент } \\
\text { пористости, д. е. } \\
\text { *甲, d.e. } \\
\end{array}$ & $\begin{array}{c}\text { *коэффициент } \\
\text { нефтенасыщенности, д. е. } \\
* S_{\text {oil }}, \text { d.e. } \\
\end{array}$ & $\begin{array}{l}* \rho_{\text {вп, }} \mathrm{oM} \cdot \mathrm{M} \\
* \mathrm{R}_{\mathrm{o}}, \mathrm{om} \cdot \mathrm{m}\end{array}$ \\
\hline $\mathrm{F}_{1}{ }^{1}$ & 21 & 0,14 & 0,77 & 5,4 \\
\hline $\mathrm{O}_{1}{ }^{2}$ & 12 & 0,14 & 0,62 & - \\
\hline $\mathrm{O}_{1}{ }^{3}$ & 11 & 0,17 & 0,70 & 9,4 \\
\hline $\mathrm{O}_{1}{ }^{4}$ & 12 & 0,15 & 0,64 & 6,3 \\
\hline $\mathrm{Ю}_{3}$ & 15 & 0,14 & 0,65 & 6,3 \\
\hline $\mathrm{Ю}_{4}$ & 14 & 0,13 & 0,62 & 5,9 \\
\hline $\begin{array}{l}\text { (диапазон значений), среднее } \\
\text { (range of values), average }\end{array}$ & $(11,0-21,0) 14,2$ & $(0,13-0,17) 0,14$ & $(0,62-0,77) 0,67$ & $(5,4-9,4) 6,7$ \\
\hline
\end{tabular}

*средневзвешенные значения по 14 скважинам; **для нефтенасыщенных пластов.

*weighted average values for 14 wells; **oil saturated formations.

Таблица 2. Значение геофизических параметров баженовской свиты в разрезах скважин Останинского месторождения

Table 2. Values of geophysical parameters of the Bazhenov suite of well sections of the Ostaninskoe field

\begin{tabular}{|c|c|c|c|c|c|}
\hline $\begin{array}{c}\text { Скважина } \\
\text { Well }\end{array}$ & $\begin{array}{c}\text { Мощность, м } \\
\text { Power, m }\end{array}$ & $\begin{array}{c}\text { Вариации ПС, мB } \\
\text { Variations of SP, mV }\end{array}$ & $\begin{array}{c}\text { КС*, ом·м } \\
\text { KS, om·m }\end{array}$ & $\begin{array}{c}\text { ГК*, мкР/ч } \\
\text { GR, mkR/hr }\end{array}$ & $\begin{array}{c}\text { HГК*, усл. ед. } \\
\text { NGK, c.u. }\end{array}$ \\
\hline $417 \Pi$ & 19,0 & $\pm 0,5$ & $98 / 40$ & $62 / 44$ & $2,7 / 1,7$ \\
\hline $418 \Pi$ & 22,0 & $\pm 2,5$ & $99 / 32$ & $57 / 40$ \\
\hline $436 \mathrm{P}$ & 16,0 & $\pm 1,6$ & $138 / 42$ & $43 / 36$ \\
\hline
\end{tabular}

* максимальное значение/средний уровень.

*maximum value/average.

На фоне вмещающих пород баженовская свита выделяется отрицательными аномалиями НГК, положительными аномалиями радиоактивности и электрического сопротивления. Аномальное отображение баженовской свиты на диаграммах КС и ГК связано с высоким содержанием органического вещества - высокоомного адсорбента радиоактивных элементов, с высокой битуминозностью [20], а также с возможной нефтенасыщенностью [25].

Важно отметить практическое отсутствие вариаиий диаграммы метода ПС в интервале баженовской свиты.

Интересно обратить внимание на изменение УЭС по разрезу баженовской свиты. Как можем наблюдать из диаграмм КС (рис. 3), УЭС в интервале баженовской свиты увеличивается от подошвы к кровле и в основном совпадает с ростом естественной радиоактивности (ГК). Так что верхняя часть свиты является одновременно и более высокоомной, и более радиоактивной, а, следовательно, и более битуминозной, а нижняя часть свиты, соответственно, обеднена органическим веществом.

\section{Нефтегеологическая характеристика Двуреченского нефтяного месторождения}

Двуреченское нефтяное месторождение относится к Каймысовскому нефтегазоносному району. Геология месторождения представлена терригенными отложениями мезозойско-кайнозойского платформенного чехла и метаморфизованными, дислоцированные образованиями различного состава доюрского фундамента. По тектонике платформенного чехла месторождение приурочено к трем локальным подняти- ям: Междуреченскому, Лёсмуровскому и ЗападноМоисеевскому, расположенным в южной части Каймысовского свода - структуры I порядка ЗападноСибирской плиты (рис. 4).

Нефтегазоносность Двуреченского месторождения составляют 4 продуктивных пласта: $Ю_{1}, Ю_{1}^{2}$, $Ю_{1}^{\mathrm{M}}$ и $Ю_{1}^{3}$. Основным продуктивным пластом и объектом разработки является пласт $Ю_{1}^{3}$.

$B$ nласте $Ю_{l}{ }^{l}$ присутствует одна залежь на Двуреченском поднятии, который является верхним трансгрессивным пластом, сложенным прибрежноморскими фациями мелководного шельфа и представлен серыми мелкозернистыми песчаниками кварц-полевошпатового и полевошпатово-кварцевого состава. Среднее значение пористости составляет $15,8 \%$, проницаемости - 12 мД.

Пласт $Ю_{1}^{2}$ представлен песчаниками среднемелкозернистыми полевошпатово-кварцевыми, иногда граувакковыми с глинистым (каолинитгидрослюдистым), изредка карбонатным цементом. В целом по пласту пористость составляет 14,9 \%, проницаемость -7 мД.

Пласт $Ю_{1}{ }^{M}$ имеет прибрежно-морское происхождение и представлен песчаниками крупно-, средне- и мелкозернистыми, полевошпатово-кварцевыми, граувакковыми с глинисто-карбонатным поровым и пленочно-поровым цементом. По пласту пористость составляет $15,3 \%$, проницаемость - 8 мД.

Пласт $Ю_{1}^{3}$ является основным продуктивным пластом Двуреченского месторождения. Формирование фильтрационно-емкостных свойств коллектора происходило под воздействием седиментационных и постседиментационных процессов. Характерной осо- 
бенностью отложений пласта является значительная изменчивость литолого-петрографических и фильтрационно-емкостных свойств, что объясняется различиями в фациальных обстановках формирования данных отложений. Пласт $Ю_{1}{ }^{3}$ разделен на две пачки: А и Б. Пачка $A$ представляет собой верхнюю высокопроницаемую часть пласта $\mathrm{Ю}_{1}^{3}$. В литологическом отношении эта часть пласта представлена песчаниками крупно-, средне- и мелкозернистыми полевошпатово-кварцевыми граувакковыми, иногда аркозо- граувакковыми. Средние значения пористости и проницаемости соответственно составляют 20,6 \% и 680 мД. Пачка $Б$ представляет собой нижнюю, менее проницаемую, часть пласта $\mathrm{Ю}_{1}{ }^{3}$. В литологическом отношении эта часть пласта представлена песчаниками, в основном мелкозернистыми полевошпатовокварцевыми граувакковыми. Средние значения пористости и проницаемости соответственно составляют $15 \%$ и 7 мД.

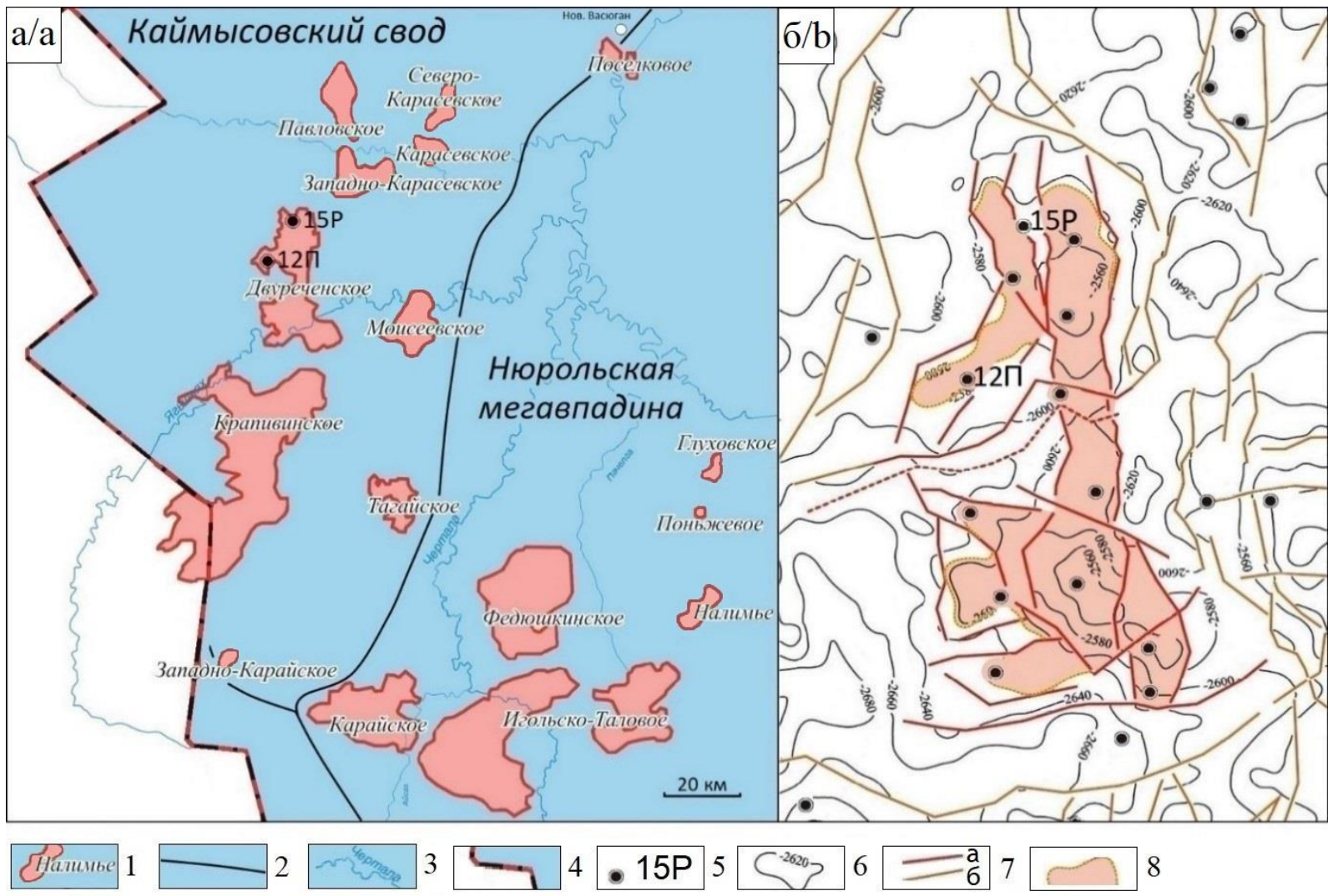

Рис. 4. Обзорная схема территории исследований - группь месторождений Каймылсовского нефтегазоносного района Томской области (а) и контур Двуреченского нефтяного месторождения (б). K $а$ : 1 - месторождение; 2 - контур структуры I порядка платформенного чехла [20]; 3 - речная сеть; 4 - административная граница Томской области. К б: 5 - скважина и ее номер; 6- изогипса кровли подугольной пачки пласта $Ю_{1}^{3}$, м; 7 разрывное нарушение ( $а$ - установленное, 6 - предполагаемое); 8 - водонефтяной контакт по пласту $\mathrm{O}_{1}{ }^{3}$

Fig. 4. Overview of the territory of research - groups of fields of the Kaimysovskoe oil and gas region of the Tomsk Region (a) and the contour of the Dvurechenskoe oil field (b). To a: 1 is the field; 2 is the first-order outline of the platform cover [20]; 3 is the river network; 4 is the administrative border of the Tomsk region. To b: 5 is the well and its number; 6 is the isohypsum of the roof of the subsurface pack of the $J_{1}^{3}$ formation, $m ; 7$ is the discontinuous violation (a is the established, $b$ is the alleged); 8 is the oil-water contact in the $J_{1}^{3}$ reservoir

\section{Геофизическая характеристика юрских пластов Дву- реченского месторождения}

Для анализа данных геофизических исследований и петрофизики юрских пластов Двуреченского месторождения были выбраны разрезы поисковых и разведочных скважин (рис. 4, б). Исследование заключалось в анализе результатов методов ПС, ГК, КС и плотности тепловых нейтронов (НКТ) по разрезам скважин разной продуктивности (например, скважина 12П с нефтенасыщенными пластами и скважина 15P с водонасыщенными пластами в юрской части разреза).
Юрский разрез скважин представлен песчаниками, глинами, плотными песчаниками, алевролитами, которые стандартно [24] отражаются в показаниях методов каротажа (рис. 5, $a, 6$ ). Баженовская свита трансгрессивно, согласно перекрывает аргиллиты георгиевской свиты. При этом георгиевская свита хорошо обособляется большими значениями естественной гамма-активности от залегающей ниже верхневасюганской подсвиты и меньшими значениями - от перекрывающей баженовской свиты. 


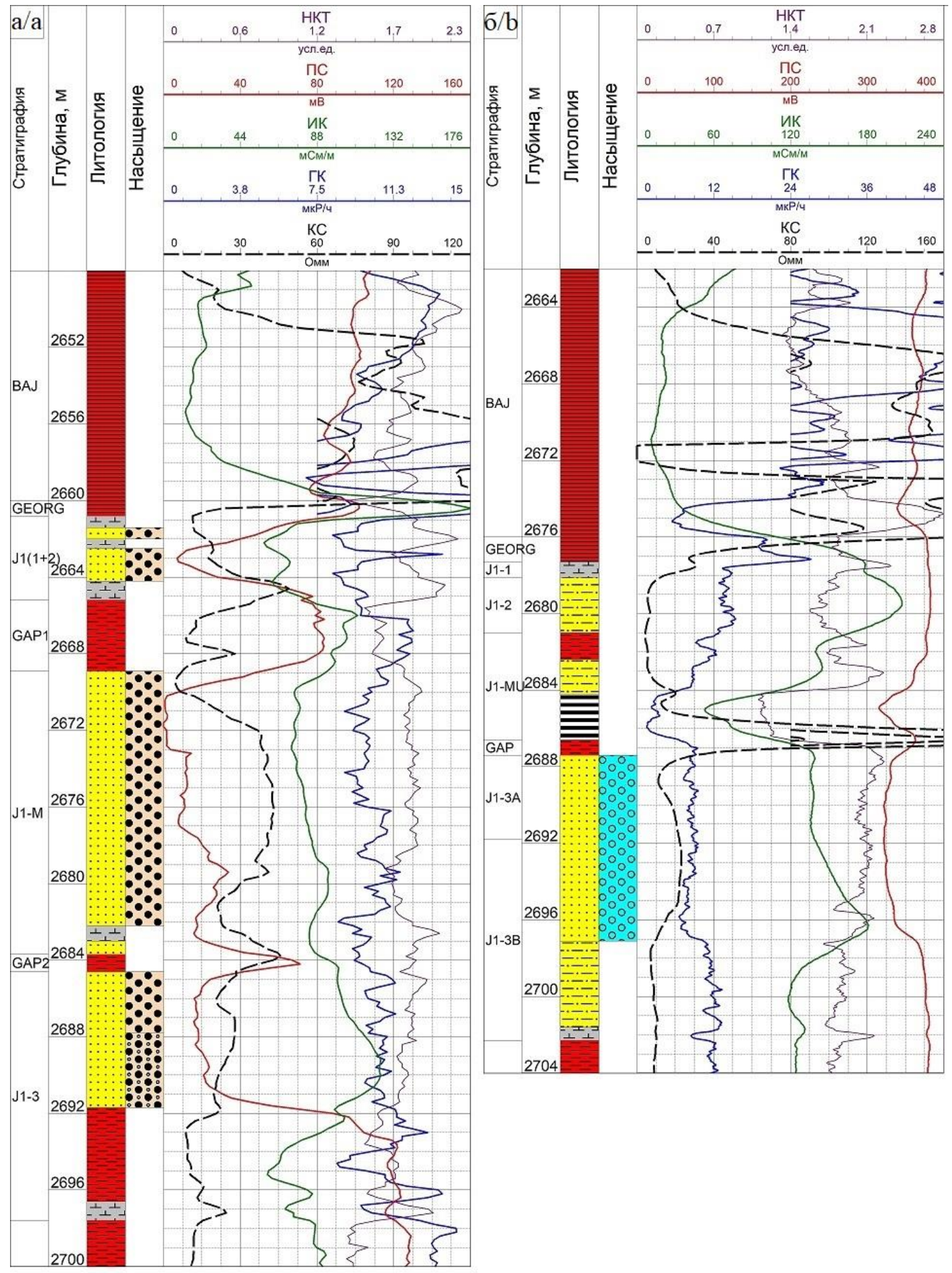

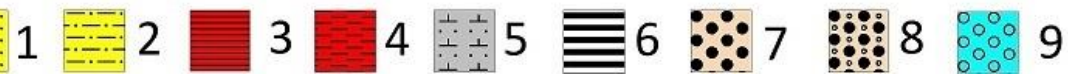

Pис. 5. Двуреченское месторождение. Геофизическая характеристика разрезов скважин 12П (а) и 15P (б) в интервалах баженовской свиты (ВАJ) и пластов $Ю_{l}{ }^{l}(J 1-1), Ю_{l}^{2}(J 1-2), Ю_{l}^{M}(J 1-M), Ю_{l}^{M y}(J 1-M U), O_{l}^{3}(J 1-3)$, $Ю_{I}{ }^{3 A}(\mathrm{Jl}-3 \mathrm{~A}), Ю_{I}{ }^{35}(\mathrm{Jl}-3 \mathrm{~B}): 1$ - песчаник; 2 - алевролит; 3 - аргиллит; 4 - глина; 5 - карбонатная порода; 6 уголь; 7 -нефтенасыщенный; 8 -нефтеводонасыщенный; 9 -водонасыщенный

Fig. 5. Dvurechenskoe field. Geophysical characteristics of the sections of wells $12 P(a)$ and $15 R(b)$ in the intervals of the Bazhenov suite and formations $J_{1}{ }^{l}, J_{1}{ }^{2}, J_{I}{ }^{M}, J_{I}{ }^{M U}, J_{I}{ }^{3}, J_{I}{ }^{3 A}, J_{I}{ }^{3 B}: 1$ is the sandstone; 2 is the siltstone; 3 is the mudstone; 4 is the clay; 5 is the carbonate rock; 6 is the coal; 7 is the oil saturated; 8 is the oil saturated; 9 is the water saturated 
Таблица 3. Результаты расчета удельного электрического сопротивления $\rho_{n}$ нефтенасыщенных $\left(\rho_{\text {ни }}\right)$ и водонасыщенных $\left(\rho_{\text {вn }}\right)$ пластов Двуреченского месторождения

Table 3. Results of calculation of the electrical resistivity $R_{t}$ of oil-saturated $\left(R_{t}\right)$ and water-saturated $\left(R_{o}\right)$ layers of the Dvurechenskoe field

\begin{tabular}{|c|c|c|c|c|}
\hline $\begin{array}{c}\text { Пласт } \\
\text { Formation }\end{array}$ & $\begin{array}{l}{ }^{*} \rho_{\mathrm{нп}}, \mathrm{OM} \cdot \mathrm{M} \\
* \mathrm{R}_{\mathrm{t}}, \mathrm{om} \cdot \mathrm{m}\end{array}$ & $\begin{array}{c}\text { *коэффициент пористости, } \\
\text { д. е. } \\
* \varphi, \text { d. е. } \\
\end{array}$ & $\begin{array}{c}\text { *коэффициент нефтенасыщенности, } \\
\text { д. е. } \\
\mathrm{S}_{\mathrm{oil}}, \text { d. e. } \\
\end{array}$ & $\begin{array}{l}{ }^{*} \rho_{\mathrm{Bп},} \mathrm{OM} \cdot \mathrm{M} \\
{ }^{*} \mathrm{R}_{\mathrm{o}}, \mathrm{om} \cdot \mathrm{m}\end{array}$ \\
\hline $\mathrm{O}_{1}{ }^{1}$ & 6 & 0,16 & 0,48 & 1,9 \\
\hline $\mathrm{O}_{1}{ }^{2}$ & 7 & 0,15 & 0,60 & 3,6 \\
\hline $\mathrm{F}_{1}^{\mathrm{M}}$ & 7 & 0,16 & 0,54 & - \\
\hline $\mathrm{\wp}_{1}^{3 \mathrm{~A}}$ & 12 & 0,20 & 0,51 & 4,5 \\
\hline $\mathrm{F}_{1}^{3 \mathrm{~b}}$ & 7 & 0,15 & 0,45 & 4,6 \\
\hline $\begin{array}{l}\text { (диапазон значений), среднее } \\
\text { (rangeofvalues), average }\end{array}$ & $(6,0-12,0) 7,8$ & $(0,15-0,20) 0,16$ & $(0,45-0,60) 0,52$ & $(1,9-4,6) 3,6$ \\
\hline
\end{tabular}

*средневзвешенные значения по 14 скважинам; **для нефтенасыщенных пластов.

*weighted average values for 14 wells; **oil saturated formations.

Баженовская свита отличается от вмещающих ее пород аномальными показаниями геофизических методов и, в первую очередь, высоким сопротивлением по КС и высокой радиоактивностью по ГК, а также повышенными значениями показаний НКТ.

Для оценки удельного электрического сопротивления юрских пластов-коллекторов Двуреченского месторождения были использованы данные геофизических исследований по разрезу 14 скважин (рис. 4, б) материалы Томского филиала ФГУ «ТФГИ по СФО». Судя по результатам расчета УЭС как нефтенасыщенных пластов, так и водонасыщенных пластов (табл. 3), юрские пласты-коллекторы Двуреченского месторождения имеют заметно низкие значения: для нефтенасыщенных пластов УЭС $=6 . .12$ ом*м при среднем значении 8 ом*м, для водонасыщенных пластов УЭС $=2 \ldots .5$ ом*м при среднем значении $3 . .4$ ом*м.

\section{Геофизическая характеристика баженовской свить}

\section{Двуреченского месторождения}

Для характеристики петрофизики аргиллитов баженовской свиты на Двуреченском нефтяном месторождении проанализированы разрезы скважин 15Р (с водоносными пластами $Ю_{1}{ }^{3 \mathrm{~A}}, \mathrm{Ю}_{1}{ }^{3 \mathrm{5}}$ ) и $12 П$ (с нефтеносными пластами $\left.Ю_{1}{ }^{1}, Ю_{1}{ }^{\mathrm{M}}\right)$. Был сделан качественный и количественный (статистический) анализ показаний методов ПС, КС, ГК и НКТ (табл. 4).

Таблица 4. Значения геофизических параметров баженовской свиты разрезов скважин Двуреченского месторождения

Table 4. Values of geophysical parameters of the Bazhenov suite of well sections of the Dvurechenskoe field

\begin{tabular}{|c|c|c|c|c|c|}
\hline $\begin{array}{c}\text { Скважина } \\
\text { Well }\end{array}$ & $\begin{array}{c}\text { Мощность, } \\
\text { м } \\
\text { Power, m }\end{array}$ & $\begin{array}{c}\text { Вариации } \\
\text { ПС, мB } \\
\text { Variations } \\
\text { SP, mV }\end{array}$ & $\begin{array}{c}\mathrm{KC}^{*}, \\
\text { ом·м } \\
\mathrm{KS}, \\
\mathrm{om} \cdot \mathrm{m}\end{array}$ & $\begin{array}{c}\text { ГК*, } \\
\text { мкP/ч } \\
\mathrm{GR}, \\
\mathrm{mkR} / \mathrm{hr}\end{array}$ & $\begin{array}{c}\mathrm{HKT}^{*}, \\
\text { усл. ед. } \\
\text { NKT, c.u. }\end{array}$ \\
\hline $15 \mathrm{P}$ & 13,7 & $\pm 5,0$ & $249 / 111$ & $120 / 59$ & $2,8 / 1,8$ \\
\hline $12 \Pi$ & 12,0 & $\pm 8,0$ & $149 / 95$ & $54 / 40$ & $2,3 / 1,9$ \\
\hline
\end{tabular}

*максимальное значение/средний уровень.

*maximum value/average.

Важно отметить значительные вариаџии диаграммы метода ПС в интервале баженовской свиты как в продуктивной, так и в непродуктивной скважинах.
Интересно заметить, что баженовская свита в разрезе скважины 12 П с нефтепродуктивными юрскими пластами обладает заметно меньшей радиоактивностью и несколько меньшим УЭС, по сравнению с непродуктивной скважиной 15Р, что, возможно, указывает на некоторое обеднение баженовской свиты в районе скважины 12П органическим веществом.

\section{Оценка карбонатности юрских пластов-коллекторов}

\section{Останинского и Двуреченского месторождений}

Определение общей карбонатности пород $\left(\mathrm{C}_{\text {карб. }}\right)$ пластов-коллекторов проводилось по поисковооценочным (417П, 12П) и разведочным (436Р, 15Р) скважинам Останинского и Двуреченского месторождений с помощью объемного газометрического метода. Данный метод основан на определении объема выделившегося углекислого газа при взаимодействии породы с соляной кислотой в приборе Кларка [26].

Из графиков (рис. 6) видно, что юрские разрезы изучаемых скважин 417П и 436Р Останинского месторождения характеризуются более высоким содержанием карбонатных минералов.

Простой расчет общей карбонатности юрских пластов-коллекторов показывает, что средние значение

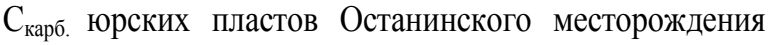
составляет 5,4 \%, а Двуреченского - 1,1 \%. Таким образом, в интервалах юрских пластов Останинского месторождения, имеющего залежи в доюрском НГК,

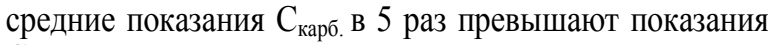

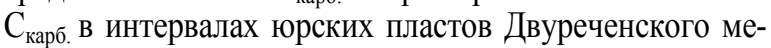
сторождения, не имеющего залежи в доюрском НГК.

\section{Сопоставление и анализ}

Напомним, что Останинское нефтегазоконденсатное месторождение представляет тип месторождений юговостока ЗСП (Томская область), имеющих залежи как в юрском, так и в доюрском НГК. В то время как Двуреченское нефтяное месторождение представляет тип месторождений, имеющих залежи в юрско-меловых НГК, но не имеющих залежи в доюрском НГК.

Проведенные исследования позволили установить и оценить априорно (концептуально) предполагаемые различия петрофизической характеристики юрских пластов Останинского и Двуреченского месторождений, перекрывающих доюрские образования. 


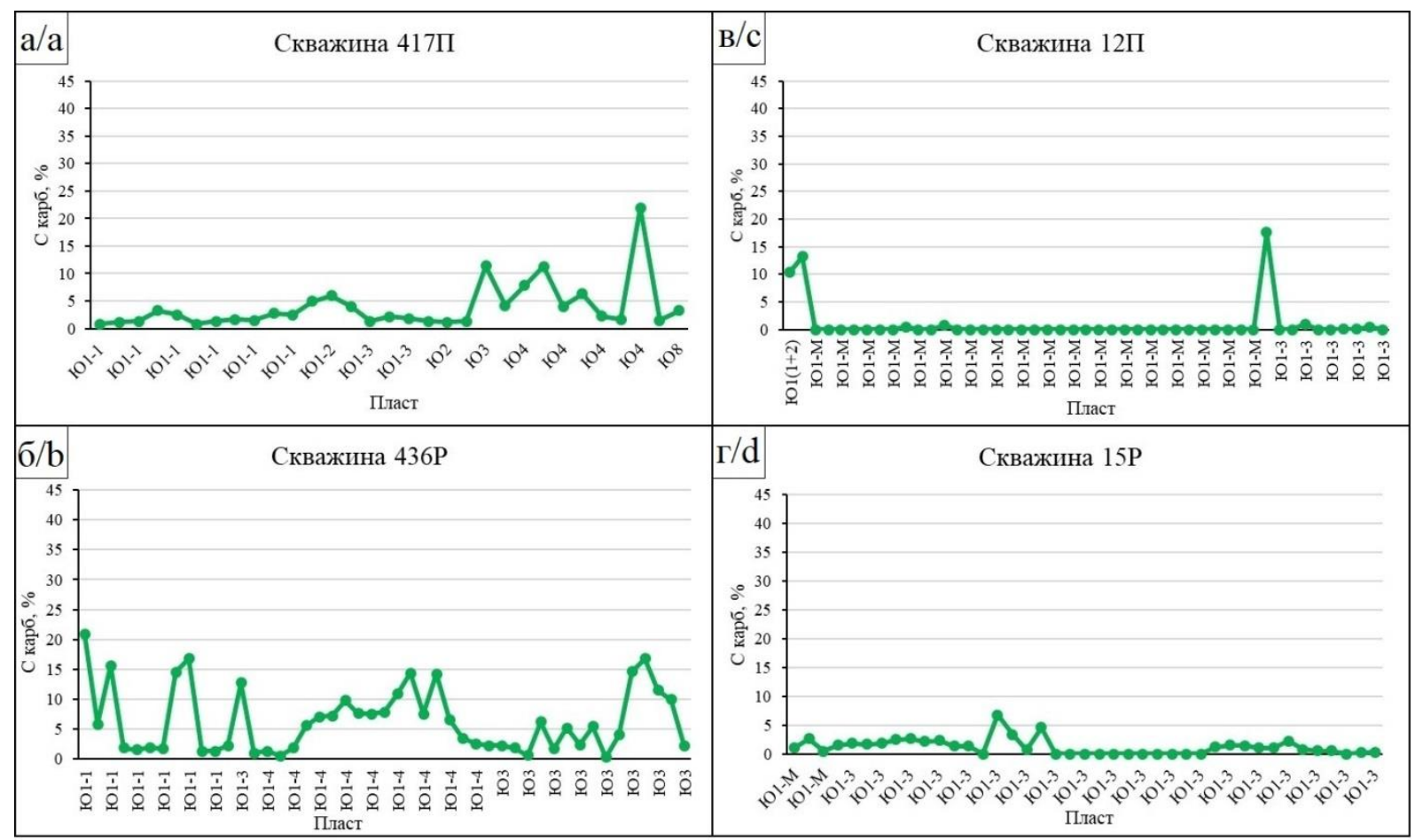

Pис. 6. Карбонатность ( $C_{\text {карб }}$ ) образцов керна скважин $417 П$ (а), $436 P$ (б) Останинского и 12П (в), $15 P$ (2) Двуреченского месторождений

Fig. 6. Carbonate (Ccarb.) core samples of wells $417 P(a), 436 R(b)$ of Ostaninskoe and $12 P(c), 15 R(d)$ of the Dvurechenskoe field

Исследованиями установлено, что юрские пластыколлекторы Останинского месторождения, по результатам расчета УЭС 14-ти поисково-оценочных и разведочных скважин, имеют для нефтенасыщенных пла-

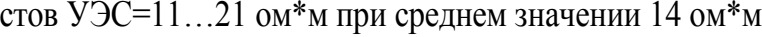
для водонасыщенных пластов - УЭС $=5 \ldots 9$ ом* м при среднем значении 7 ом* $^{*}$.

По результатам расчета УЭС 14-ти поисковооценочных и разведочных скважин Двуреченского месторождения установлено, что юрские пластыколлекторы имеют для нефтенасыщенных пластов УЭС $=6 \ldots 12$ ом* $^{*}$ при среднем значении $8 \mathrm{om}^{*} \mathrm{M}$, для водонасыщенных пластов - УЭС $=2 \ldots 5$ ом*м при среднем значении $3 \ldots 4$ ом* м.

Как видно, юрские пласты-коллекторы Останинского месторождения существенно, аномально, практически в два раза, более высокоомные, чем юрские пласты-коллекторы Двуреченского месторождения.

Вероятно, аномальная высокоомность транзитных юрских пластов Останинского месторождения есть следствие возможной нисходящей(?)/ восходящей(?) миграчии УВ-флюидов, обеспечивающей или нефтесбор(?) в ловушках доюрского НГК или являющейся элизией(?) углеводородов доюрского НГК, как самостоятельного аккумулирующего-генерирующего комплекса. В результате миграции химически агрессивных УВ флюидов в юрском разрезе происходят процессы наложенного эпигенеза, приводящие к вторичной, наложенной, и, как следствие, аномальной карбонатизации транзитных пластовколлекторов, а, следовательно, к аномальному увеличению их УЭС.
Аномальность карботнатизации юрских пластовколлекторов Останинского месторождения $\left(\mathrm{C}_{\text {карб }}\right.$ порядка 5 \%) показана выше. Следует заметить, что повышенная карбонатизация юрских пластов Останинского месторождения закономерно приводит к снижению пористости пластов. Так, если обобщенная пористость юрских пластов Двуреченского месторождения составляет $16 \%$ (табл. 3), то пористость юрских пластов Останинского месторождения заметно ниже - 14 \% (табл. 1).

Что касается геофизической характеристики баженовской свиты, то она оказывается значимо разной у Останинского и Двуреченского месторождений.

Исследованиями установлено, что на Останинском месторождении геофизические характеристики баженовской свиты следующие: вариации показаний метода $\Pi \mathrm{C}= \pm(0,5 \ldots 2,5) \mathrm{мB}$; средний уровень УЭС=32..42 ом*м: средний уровень естественной радиоактивности $36 . .44$ мкР/ч. В то время как на Двуреченском место-

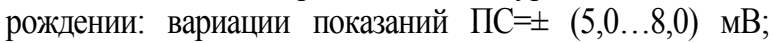
средний уровень УЭС $=95 \ldots 111$ ом$^{*}$ м: средний уровень естественной радиоактивности $40 \ldots 59$ мкР/ч.

Возможно, что на Останинском месторождении отсутствие вариаций ПС свидетельствует о ее более однородном (выравненном?) составе, а низкий уровень УЭС и естественной радиоактивности говорит о более бедном (обедненном?) содержании органического вещества.

Конечно, замеченные аномальные отличия геофизической характеристики баженовской свиты Останинского нефтегазоконденсатного месторождения, имеющего залежи в доюрском НГК, пока остаются артефактом, не имеющим весомого генетического обоснования. 
Есть только предварительные косвенные признаки, допускающие обеднение баженовской свиты органическим веществом по причине того, что, наряду с девонскими доманиками, баженовская свита является источником УВ для палеозойских залежей [27].

\section{Заключение}

Результаты проведенных исследований на Останинском и Двуреченском месторождениях дали дополнительные весомые аргументы ранее высказанной и аргументированной [16] гипотезы аномальности петрофизических характеристик юрского разреза, перекрывающего залежи доюрского нефтегазоносного комплекса.

Для дальнейшего обоснования гипотезы уникальности «отражения» залежей палеозоя в геофизических параметрах перекрывающих юрских отложениях, как возможного нефтепоискового признака палеозойских залежей, предлагается:

- провести анализ геофизических и петрофизических характеристик юрского разреза на месторож-

\section{СПИСОК ЛИТЕРАТУРЬ}

1. Blackbourn G. The Palaezoic of Western Siberia. Tectonic development of Western Siberia during the Palaezoic // Russian Oil \& Gas Technologies. - 2010 - V. 21 - P. 13-23.

2. Liu X., Jin Z., Bai G. Formation and distribution characteristics of Proterozoic-Lower Paleozoic marine giant oil and gas fields worldwide // Petroleum Science. - 2017. - V. 14. - P. 237-260.

3. Белозёров В.Б., Гарсиа Бальса А.С. Перспективы поиска залежей нефти в отложениях Девона юго-восточной части Западно-Сибирской плиты // Известия Томского политехническогоуниверситета. Инжиниринг георесурсов. - 2018. - Т. 329. № 6. - C. 128-139.

4. Прогноз нефтегазоносности юрских и палеозойских отложений южных районов Западно-Сибирского бассейна / Я.В. Садыкова, М.А. Фомин, С.В. Рыжкова, Д.А. Новиков, Ф.Ф. Дульцев, А.В. Черных // Известия Томского политехнического университета. Инжиниринг георесурсов. - 2019. T. 330. - № 9. - C. 114-127.

5. Blackbourn G. Petroleum geology of the Pre-Jurassic // Russian Oil \& Gas Technologies. - 2012. - V. 28. - P. 58-69.

6. Hard-to-recover reserves of Yugra oil (West Siberia) / V.I. Isaev, S.G. Kuzmenkov, R.Sh. Ayupov, Yu.A. Kuzmin, G.A. Lobova, P.A. Stulov // Геофизический журнал. - 2019. - Т. 41. - № 1. C. $33-43$.

7. Стратегия и основы технологии поисков углеводородов в доюрском основании Западной Сибири / В.И. Исаев, Г.А. Лобова, Ю.В. Коржов, М.Я. Кузина, Л.К. Кудряшова, О.Г. Сунгурова. - Томск: Изд-во ТПУ, 2014. - 112 с.

8. Тяпкина А.Н., Тяпкин Ю.К. Синхронная сейсмическая инверсия для выявления перспективных участков в карбонатных породах юго-восточной части Западно-Сибирской платформы // Геофизический журнал. - 2019. - Т. 41. - № 1. - С. 76-94.

9. Гаврилов В.П. Геодинамическая модель нефтегазоносности Западной Сибири // Геология нефти и газа. - 2012. - № 2. C. $60-64$

10. Peters K., Walters C., Moldowan J. The biomarker guide: biomarkers and isotopes in petroleum systems and Earth history. 2nd ed. - New York: Cambridge University press, 2005. - V. 2. $698 \mathrm{p}$.

11. Mechanism of hydrocarbon migration of Paleozoic clastic rocks in Western Section of the Tabei Uplift, Tarim Basin: YM34 silurian accumulations as a case / W. Guan, M. Zha, T. Li, J. Qu, F. Li, L. Deng, Y. Tan, C. Zhang // Proc. of the International Field Exploration and Development Conference. - Singapore, 2018. P. 782-797.

12. Кузина М.Я., Коржов Ю.В., Исаев В.И. Геохимическое и литологическое обоснование концепции «Главного источника» дении/площади, принадлежащей Нюрольской структурно-фациальной зоне по палеозою, но не имеющей залежей в доюрском нефтегазоносном комплексе;

- детализировать анализ карбонатности транзитных юрских пластов, с выявлением и определением доли вторичной, наложенной карбонатизации, с использованием комплекса данных/способов, включая инновационную технологию [17] интерпретации материалов геофизических исследований скважин;

- выполнить массовыци, представительный анализ геофизических характеристик баженовской свиты, что, возможно, даст дополнительные аргументы той или другой концепции «главного источника» формирования залежей в доюрском нефтегазоносном комплексе.

Благодарим рецензента за предметную и развернутую рецензию, позволяюшую лучше понять фундаментальные и прикладные аспекты проблемьл.

доюрских залежей нефти Красноленинского свода // Известия Томского политехнического университета. - 2014. - Т. 324. № $1 .-$ C. 32-38

13. Карпов В.А. Некоторые замечания по проблемам нефтегазообразования и нефтегазонакопления // Недропользование XXI век. - 2017. - № 4. - С. 142-149.

14. Абукова Л.А. Нисходящая миграция подземных вод и углеводородов в осадочных нефтегазоносных бассейнах // Геология, геофизика и разработка нефтяных и газовых месторождений. - 2008. - № 10. - С. 23-31.

15. Мельник И.А. Выявление вторично преобразованных терригенных коллекторов на основе статистической интерпретации материалов ГИС // Геофизика. - 2013. - № 4. - С. 29-36.

16. Алеева А.О., Исаев В.И. Сравнительная петрофизическая характеристика разрезов Герасимовского и Крапивинского месторождений (в связи с нефтегазоносностью доюрских отложений) // Известия Томского политехнического университета. Инжиниринг георесурсов. - 2019. - Т. 330. - № 9. C. 21-31.

17. Мельник И.А., Недоливко Н.М., Зимина С.В. Вторичные карбонаты юрских песчаных отложений как показатели продуктивности палеозоя // Известия Томского политехнического университета. Инжиниринг георесурсов. - 2020. - Т. 331. № 3. - С. 32-38.

18. Исаев Г.Д. Фациальные модели девона Нюрольской зоны и основные критерии районирования палеозоя ЗападноСибирской плиты // Литосфера. - 2011 - № 6. - С. 27-37.

19. Решение 6-го Межведомственного стратиграфического совещания по рассмотрению и принятию уточненных стратиграфических схем мезозойских отложений Западной Сибири. Новосибирск, 2003. - Новосибирск: СНИИГГиМС, 2004. $114 \mathrm{c}$.

20. Конторович В.А. Тектоника и нефтегазоносность мезозойскокайнозойских отложений юго-восточных районов Западной Сибири. - Новосибирск: Изд-во СО РАН, 2002. - 253 с.

21. Petersilie V., Komar N., Frenkel S. Methodological approaches to the calculation of reserves of the Bazhenov formation // Conference Proceedings, EAGE/SPE Workshop on Shale Science 2019. Moscow, Russia, 2019. - V. 2019. - P. 1-5.

22. Hürlimann M.D. Well Logging // Emagres. - 2012. - V. 1. - № 1. P. 223-232.

23. Yabe S., Fukuchi R., Hamada Y. Simultaneous estimation of in situ porosity and thermal structure from core sample measurements and resistivity log data at Nankai accretionary prism // Earth Planets Space. - 2019. - V. 71. - P. 1-15.

24. Niab D., Dinaldson E.C. Petrophysics. - Oxford: Elsevier, 2004. $926 \mathrm{p}$. 
25. Jarvie D.M. Shale resource systems for oil and gas: Part 2 - Shaleoil resource systems // Shale reservoirs - giant resources for the 21st century: AAPG Memoir 97. - Texas, U.S.A, - 2012. - P. 89-119.

26. Digital petrophysics and standard laboratory methods for determining terrigenous container rocks capacitive properties V.M. Aleksandrov, A.A. Ponomarev, G. Imashev, V.E. Makhatova, A.N. Shakibayeva // Journal of Industrial Pollution Control. - 2017. - V. 33. - № 1. - P. 1048-1051.
27. Галиева М.Ф., Крутенко Д.С. Геолого-геофизические аргументы гипотезы «баженовского источника» доюрских залежей нефти Останинской группы месторождений (Томская область) // Актуальные проблемы геологии нефти и газа Сибири: Материалы 2-й Всеросс. науч. конф. молодых ученых и студентов, посв. 85-летию акад. А.Э. Конторовича. - Новосибирск: ИПЦ НГУ, 2019. - С. 22-25.

Поступила 17.06.2020 2.

\section{Информация об авторах}

Aлеева A.O., аспирант отделения геологии Инженерной школы природных ресурсов Национального исследовательского Томского политехнического университета.

Исаев В.И., доктор геолого-минералогических наук, профессор отделения геологии Инженерной школы природных ресурсов Национального исследовательского Томского политехнического университета.

Лобова Г.А., доктор геолого-минералогических наук, профессор отделения геологии Инженерной школы природных ресурсов Национального исследовательского Томского политехнического университета. 


\title{
UDC 553.98.042 \\ COMPARATIVE PETROPHYSICAL CHARACTERISTIC OF THE JURASSIC SECTIONS OF THE OSTANINSKOE AND DVURECHENSKOE FIELDS (IN RELATION TO PETROLEUM POTENTIAL OF PRE-JURASSIC DEPOSITS OF THE TOMSK REGION)
}

\author{
Anna O. Aleeva ${ }^{1}$, \\ rastorguevaAO_90@mail.ru \\ Valery I. Isaev1,
isaevvi@tpu.ru \\ Galina A. Lobova', \\ lobovaga@tpu.ru \\ 1 National Research Tomsk Polytechnic University, \\ 30, Lenin avenue, Tomsk, 634050, Russia.
}

The relevance of the research is caused by the importance of reproduction and expansion of the resource base of hydrocarbons in Western Siberia based on the assessment of prospects and development of the horizon of the contact zone and the Paleozoic, where the deposits belong to hard-to-recover reserves.

The aim of the research is to consistently justify the criteria for forecasting and prospecting Paleozoic hydrocarbon deposits based on the hypothesis of anomalies in the petrophysical characteristics of Jurassic formations - the uniqueness of the "reflection» of Paleozoic deposits in the geophysical parameters of the overlapping Mesozoic-Cenozoic section. This hypothesis was formulated and reasoned earlier by the results of studying the well sections of the Gerasimovskoe field with Paleozoic oil deposits and the Krapivinskoe fields with Jurassic oil deposits.

The objects: geophysical and petrophysical parameters of the Jurassic reservoir layers and intervals of the Bazhenov suite at the Ostaninskoe oil and gas condensate field, which has deposits in the pre-Jurassic base, and at the Dvurechenskoe oil field with only Jurassic oil deposits.

Methods. To characterize the Jurassic reservoirs, petrophysical calculations of electrical resistivity were performed, the data of induction logging and resistivity logging were used along sections of 28 wells of the Ostaninskoe and Dvurechenskoe deposits. To characterize the petrophysics of mudstones of the Bazhenovsuite, a qualitative and quantitative (statistical) analysis of the readings of the methods of potentials of spontaneous polarization, apparent resistence, and gamma-ray logging were carried out. The carbonate content of reservoir rocks was estimated using the volumetric gasometric method.

Results. It was established that Jurassic reservoirs of the Ostaninskoe field have resistivity of $11 \ldots 21 \mathrm{om} \cdot \mathrm{m}$ for oil-saturated reservoirs and resistivity of $5 . . .9 \mathrm{om} \cdot \mathrm{m}$ for water-saturated reservoirs. Jurassic reservoirs of the Dvurechenskoe field have a resistivity of $6 . .12 \mathrm{om} \cdot \mathrm{m}$ for oil-saturated formations and a resistivity of $2 . . .5 \mathrm{om} \cdot \mathrm{m}$ for water-saturated formations. The Jurassic reservoirs of the Ostaninskoe field are abnormally, two times higher, resistive than the Jurassic reservoirs of the Dvurechenskoe field. The total carbonate content of the Jurassic strata of the Ostaninskoe field is 5,4\%, and the Dvurechenskoe field is 1,1\%. It was shown that at the Ostaninskoe field, variations in the readings of the PS method are $\pm(0,5 \ldots 2,5) \mathrm{mV}$, the resistivity level is $32 \ldots .42 \mathrm{om} \cdot \mathrm{m}$, and the level of natural radioactivity is $36 \ldots 44 \mathrm{mkR} / \mathrm{hr}$. At the Dvurechenskoe field, variations in the PS readings are $\pm(5,0 \ldots 8,0) \mathrm{mV}$, the resistivity level is $95 . .111 \mathrm{om} \cdot \mathrm{m}$, the level of natural radioactivity is $40 . .59 \mathrm{mkR} / \mathrm{hr}$. The results of the research at the Ostaninskoe and Dvurechenskoe fields are fully consistent with the previously expressed and reasoned hypothesis of the anomalous petrophysical characteristics of the Jurassic section, overlapping deposits of the pre-Jurassic oil and gas condensate field.

\section{Key words:}

Paleozoic hydrocarbon deposits, petrophysical characteristics of Jurassic reservoirs and the Bazhenov suite, unique «reflection» of the Paleozoic deposits in the geophysical parameters of the Jurassic section, criterion of forecasting and prospecting of hydrocarbon deposits of the Paleozoic, Tomsk region.

The authors express thanks to the reviewer for meaningful and detailed review which allows understanding better the fundamental and applied aspects of the issue.

\section{REFERENCES}

1. Blackbourn G. The Palaezoic of Western Siberia. Tectonic development of Western Siberia during the Palaezoic. Russian Oil \& Gas Technologies, 2010, vol. 21, pp. 13-23.

2. Liu X., Jin Z., Bai G. Formation and distribution characteristics of Proterozoic-Lower Paleozoic marine giant oil and gas fields worldwide. Petroleum Science, 2017, vol. 14, pp. 237-260.

3. Belozerov V.B., Garcia A.S. Prospects of searching for oil reservoirs in the Devonian deposits of the south-eastern part of the Western-Siberian plate. Bulletin of the Tomsk Polytechnic University. Geo Assets Engineering, 2018, vol. 329, no. 6, pp. 128-139. In Rus.
4. Sadykova Y.V., Fomin M.A., Ryzhkova S.V., Novikov D.A., Dultsev F.F., Chernykh A.V. Forecast of oil-and-gas content in Jurassic and Paleozoic deposits of West Siberia southern regions. Bulletin of the Tomsk Polytechnic University. Geo Assets Engineering, 2019, vol. 330, no. 9, pp. 114-127. In Rus.

5. Blackbourn G. Petroleum geology of the Pre-Jurassic. Russian Oil \& Gas Technologies, 2012, vol. 28, pp. 58-69.

6. Isaev V.I., Kuzmenkov S.G., Ayupov R.Sh., Kuzmin Yu.A., Lobova G.A., Stulov P.A. Hard-to-recover reserves of Yugra oil (West Siberia). Geophysical journal, 2019, vol. 41, no. 1, pp. 33-43.

7. Isaev V.I., Lobova G.A., Korzhov Yu.V., Kuzina M.A, Kudryashova L.K., Sungurova O.G. Strategiya i osnovy tekhnologii poiskov uglevodorodov v doyurskom osnovanii Zapadnoy Sibiri [Strategy 
and fundamentals of hydrocarbon search technology in the preJurassic base of Western Siberia]. Tomsk, Tomsk State University Publ., 2014. 112 p.

8. Tiapkina O.M., Tyapkin Yu.K. Simultaneous seismic inversion to identify prospective areas in carbonate rocks of the southeastern part of the West Siberian Platform. Geophysical journal, 2019, vol. 41, no. 1, pp. 76-94. In Rus.

9. Gavrilov V.P. The geodynamic model of oil and gas potential in Western Siberia. Geology of oil and gas, 2012, no. 2, pp. 60-64. In Rus.

10. Peters K., Walters C., Moldowan J. The Biomarker Guide: Biomarkers and isotopes in petroleum systems and Earth history. $2^{\text {nd }}$ ed. New York, Cambridge University press, 2005. Vol. 2, 698 p.

11. Guan W., Zha M., Li T., Qu J., Li F., Deng L., Tan Y., Zhang C. Mechanism of hydrocarbon migration of Paleozoic clastic rocks in Western Section of the Tabei Uplift, Tarim Basin: YM34 silurian accumulations as a case. Proceedings of the International Field Exploration and Development Conference.Singapore, 2018. pp. 782-797.

12. Kuzina M.A., Korzhov Yu.V., Isaev V.I. Geochemical and lithological justification of «the main source» concept of pre-Jurassic oil deposits in Krasnoleninsk arch (Tyumen region). Bulletin of the Tomsk Polytechnic University. Geo Assets Engineering, 2014, vol. 324, no. 1 , no. 32-38. In Rus.

13. Karpov V.A. Some comments on the problems of oil and gas production and oil and gas accumulation. Subsoil XXI Century, 2017, no. 4, pp. 142-149. In Rus.

14. Abukova L.A. Niskhodyashchaya migratsiya podzemnykh vod i uglevodorodov $\mathrm{v}$ osadochnykh neftegazonosnykh basseynakh [Downward migration of groundwater and hydrocarbons in sedimentary oil and gas basins]. Geology, Geophysics and Development of oil and gas field, 2008, no. 10, pp. 23-31.

15. Melnik I.A. Identification of secondary converted terrigenous reservoirs based on the statistical interpretation data GIS Geofizika, 2013, no. 4, pp. 29-36. In Rus.

16. Aleeva A.O., Isaev V.I. Comparative petrophysical characteristic of the cuts of the Gerasimovskoe and Krapivinskoe fields (in relation to petroleum potential of pre-Jurassic deposits). Bulletin of the Tomsk Polytechnic University. Geo Assets Engineering, 2019, vol. 330, no. 9, pp. 21-31. In Rus.

17. Melnik I.A., Nedolivko N.M., Zimina S.Z. Secondary carbonates of Jurassic sand deposits as indicators of the Paleozoic productivity. Bulletin of the Tomsk Polytechnic University. Geo Assets Engineering, 2020, vol. 331, no. 3, no. 32-38. In Rus.

\section{Information about the authors}

Anna O. Aleeva, postgraduate student, National Research Tomsk Polytechnic University.

Valery I. Isaev, Dr. Sc., professor, National Research Tomsk Polytechnic University.

Galina A. Lobova, Dr. Sc., professor, National Research Tomsk Polytechnic University.
18. Isaev G.D. Devonian facial models of Nyurolskaya zone and general criteria of Paleozoic districting of the Western-Siberian plate. Lithosphere, 2011, no. 6, pp. 27-37. In Rus.

19. Reshenie 6-go Mezhvedomstvennogo stratigraficheskogo soveshchaniya po rassmotreniyu i prinyatiyu utochnennykh stratigraficheskikh skhem mezozoyskikh otlozheniy Zapadnoy Sibiri [Decision of the $6^{\text {th }}$ Interdepartmental Stratigraphic Meeting on the review and adoption of updated stratigraphic schemes of Mesozoic sediments of Western Siberia]. Novosibirsk, 2003. $114 \mathrm{p}$.

20. Kontorovich V.A. Tektonika $i$ neftegazonosnost mezozoyskokavnozovskikh otlozheniy vugo-vostochnykh ravonov Zapadnov Sibiri [Tectonics and oil-and-gas bearing of the MesozoicCenozoic deposits in southeastern of the Western Siberia]. Novosibirsk, SB RAS Publ. house, 2002. 253 p.

21. Petersilie V., Komar N., Frenkel S. Methodological approaches to the calculation of reserves of the Bazhenov formation. Conference Proceedings, EAGE/SPE Workshop on Shale Science 2019. Moscow, Russia, 2019. Vol. 2019, pp. 1-5.

22. Hürlimann M.D. Well Logging. Emagres, 2012, vol. 1, no. 1, pp. 223-232.

23. Yabe S., Fukuchi R., Hamada Y. Simultaneous estimation of in situ porosity and thermal structure from core sample measurements and resistivity log data at Nankai accretionary prism. Earth Planets Space, 2019, vol. 71, pp. 1-15.

24. Niab D., Dinaldson E.C. Petrophysics. Oxford, Elsevier, 2004. $926 \mathrm{p}$

25. Jarvie D.M. Shale resource systems for oil and gas. P. 2. Shale-oil Resource Systems. Shale reservoirs - giant resources for the $21^{\text {st }}$ century: AAPG Memoir 97. Texas, U.S.A, 2012. pp. 89-119.

26. Aleksandrov V.M., Ponomarev A.A., Imashev G., Makhatova V.E., Shakibayeva A.N. Digital petrophysics and standard laboratory methods for determining terrigenous container rocks capacitive properties. Journal of Industrial Pollution Control, 2017, vol. 33, no. 1, pp. 1048-1051.

27. Galieva M.F., Krutenko D.S. Geologo-geofizicheskie argument gipotezy «bazhenovskogo istochnika» doyurskikh zalezhey nefti Ostaninskoy gruppy mestorozhdeniy (Tomskaya oblast) [Geological and geophysical arguments of the hypothesis of the «Bazhenov suite» of pre-Jurassic oil deposits of the Ostaninsky group of fields (Tomsk region)]. Novosibirsk, IPTS NGU Publ., 2019. pp. 22-25.

Received: 17 June 2020. 